\title{
Honoré de Balzac, Un Tenebroso Affare
}

\section{Marco Stupazzoni}

\section{(2) OpenEdition}

\section{Journals}

\section{Edizione digitale}

URL: http://journals.openedition.org/studifrancesi/1386

DOI: 10.4000/studifrancesi. 1386

ISSN: 2421-5856

\section{Editore}

Rosenberg \& Sellier

\section{Edizione cartacea}

Data di pubblicazione: 1 décembre 2015

Paginazione: 607

ISSN: 0039-2944

\section{Notizia bibliografica digitale}

Marco Stupazzoni, «Honoré de Balzac, Un Tenebroso Affare», Studi Francesi [Online], 177 (LIX | III) |

2015, online dal 01 décembre 2015, consultato il 06 janvier 2021. URL: http://

journals.openedition.org/studifrancesi/1386 ; DOI: https://doi.org/10.4000/studifrancesi.1386

Questo documento è stato generato automaticamente il 6 janvier 2021.

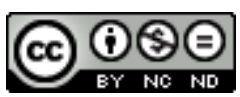

Studi Francesi è distribuita con Licenza Creative Commons Attribuzione - Non commerciale - Non opere derivate 4.0 Internazionale. 


\title{
Honoré de Balzac, Un Tenebroso Affare
}

\author{
Marco Stupazzoni
}

\section{NOTIZIA}

HONORÉ DE BALZAC, Un Tenebroso Affare, traduzione e postfazione di Felice BONALUMI, Vedano al Lambro (MB), Paginauno, 2014, «Narrativa», pp. 254.

1 Apparso tra il gennaio e il febbraio del 1841 ne «Le Commerce», Une Ténébreuse Affaire è riproposto all'attenzione del lettori italiani grazie a questa nuova ed apprezzabile traduzione di Felice Bonalumi, al quale si deve anche l'interessante postfazione (pp. 249-254) con cui si chiudono le pagine del volume.

2 Nel piano generale della Comédie humaine (cf. edizione Furne del 1846), il romanzo balzachiano è compreso all'interno delle Scènes de la vie politique, cronologicamente preceduto da Un Épisode sous la Terreur (1830), contemporaneo di Z. Marcas (1841) e seguito da Le Député d'Arcis (1847). Basato su un episodio di cronaca realmente accaduto (il rapimento del conte Dominique Clément de Ris da parte di agenti del ministro della Polizia napoleonica, Fouché), Une Ténébreuse Affaire contiene in sé le categorie e le tematiche fondanti del Noir. Questo romanzo, dal finale tutt'altro che consolatorio, ci permette, scrive Bonalumi, «una profonda riflessione, sulla società, vista da Balzac senza falsi moralismi» (p. 251): si tratta di una visione della storia nella quale, in primo piano, si collocano gli uomini che agiscono con le loro idee e i loro comportamenti. In quest'ottica, il crimine passa in secondo piano sia dal punto di vista ideologico sia sotto la prospettiva narratologica in quanto il vero personaggio del romanzo è, appunto, la Storia vista in tutte le sue sfaccettature umane e sociali. 